\title{
Determinants of Pastoral Communities for Adoption of Forage Production Technology in Yabello Rangeland, Southern Ethiopia
}

\author{
Yeneayehu Fenetahun ${ }^{1}$, Xu Xinwen ${ }^{2}$, Wang Yongdong, ${ }^{2}$ * \\ ${ }^{1}$ Xinjiang Institute of Ecology and Geography, University of China Academy of Science (UCAS), Urumqi, China \\ ${ }^{2}$ Xinjiang Institute of Ecology and Geography, Chinese Academy of Science (CAS), Urumqi, China
}

Email address:

wangyd@ms.xjb.ac.cn (Wang Yongdong)

${ }^{*}$ Corresponding author

\section{To cite this article:}

Yeneayehu Fenetahun, Xu Xinwen, Wang Yongdong. Determinants of Pastoral Communities for Adoption of Forage Production Technology in Yabello Rangeland, Southern Ethiopia. International Journal of Natural Resource Ecology and Management.

Vol. 4, No. 4, 2019, pp. 89-95. doi: 10.11648/j.ijnrem.20190404.12

Received: May 27, 2019; Accepted: June 28, 2019; Published: July 24, 2019

\begin{abstract}
The pastoral rangelands of Ethiopia are located around the peripheral or the outer edge of the country, almost surrounding the central highland mass. Livestock in Ethiopia is dependent primarily on native grasslands and crop residues. Forage production has been regarded as one of the suitable strategies for increasing feed availability for enhanced livestock production among pastoralist communities in the rangeland of Yabello and currently, forage degradation has been pointed out as the most limiting factor for livestock production in the Yabello rangeland area. There are factors determining adoption of these practices and it vary with different socio-demographical issues within the pastoral household. This study was therefore conducted to assess the socio-economic and demographic factors influencing households' participation in forage production in Yabello rangeland of Southern Ethiopia. Data was collected from 210 households and 6 extension workers in total from 216 interviewers through interviews using semi-structured questionnaire. Results indicate that gender of household head, education, social/development group membership and access to extension services were the most important factors influencing households' participation in forage production. There is need for technical support to the pastoralist households towards starting and/or joining existing social groups, through which extension and training services aimed at enhancing forage production in the Yabello range land can be offered.
\end{abstract}

Keywords: Forage Production, Pastoralists Household, Yabello, Technology Adoption

\section{Introduction}

The pastoral rangelands of Ethiopia are located around the peripheral or the outer edge of the country, almost surrounding the central highland mass [1]. Livestock in Ethiopia is dependent primarily on native grasslands and crop residues [2]. According to Alemayehu [3], Ethiopia's Livestock feed resources are mainly natural grazing and browse, crop residues, improved pasture, and agro-industrial byproducts. The feeding systems include communal or private natural grazing and browsing, cut and- carry feeding, hay and crop residues. The availability and quality of forage are not favorable year round. As a result, the gains made in the wet season are totally or partially lost in the dry season
[4]. Inadequate feed during the dry season is a major that causes decline in the productivity of ruminants [5]. Traditional knowledge of pastoralist in natural resources management and utilization has been playing important role in improving and developing range land use system in Ethiopia. The pastoralists have been using the traditional grazing management in order to cope up with the relatively arid condition of the environment, prevent overgrazing and ensure the sustainability of the resources base. Pastoralists use flexible grazing strategies. Overall, their gazing management is the result of their cumulative knowledge about resources, assessment of range condition and distribution of rainfall [6]. These traditional practices are good experiences on the basis of which it is possible to 
develop improved pastoral system. But, currently the challenge of rangeland degradation become beyond the knowledge of the community to manage on their local practice. As a result the utility or potential utility of the range land become decline in an alarming state [7]. The major cause of rangeland degradation and forage reduction on the Yebello rangeland area are drought, erratic rainfall, Bush encroachment, Over population, overstocking and different anthropogenic factors [8]. And this major causes lead to poor quality pasture, which is a major constraint to livestock production in the study area [9]. Forage degradation has been pointed out as the most limiting factor for livestock production in the Yabello rangeland area [10]. Reduced livestock productivity and increased mortality are the main effects arising from lack of livestock feed. The far reaching effects of this are low production of milk and meat, thus increased vulnerability of pastoral livelihoods and high poverty levels among the pastoral communities [5]. Being the most important requirement for livestock production, availability of high quality forage directly reflects success in livestock production [11] and therefore pastoral livelihoods. The need to increase livestock productivity in the Yabello has led to high demand for not only adequate but also better quality forage thus calling for improved forage production practices [12]. To address the problem of pasture scarcity, a number of forage production technologies have been introduced in collaboration by the government of Ethiopia and China (project name; Technology integration and demonstration of rangeland rehabilitation in lowland of Ethiopia) mainly in the Yabello rangeland. However, uptake of these technologies by pastoralist has been found to dependent on various factors. And there were no past studies that reported the constraints of adaptation of technological based forage production for sustainability utilization for livestock production in the study area. Therefore, the aim of this study was conducted to assess factors influencing adoption of forage production practices among pastoral communities in the Yabello rangeland area.

\section{Materials and Methods}

\subsection{Description of the Study Area}

The study was done at Dida Tuyura, Danbal-Waccu and Arero kebele of Yabello district Borana zone, southern Ethiopia in 2019. It is situated at $566 \mathrm{~km}$ south of Addis Ababa along Addis - Moyale road. The area of Yabello town is $5426 \mathrm{~km}^{2}$, and located between $4^{\circ} 30^{\prime} 55.81^{\prime \prime}$ and $5^{\circ} 24^{\prime} 36.39^{\prime \prime}$ north latitude and between $7^{\circ} 44^{\prime} 14.70^{\prime \prime}$ and $38^{\circ} 36^{\prime} 05.35^{\prime \prime}$ east longitude, the altitude is about 1000-1500 $\mathrm{m}$, maximum altitude of $2000 \mathrm{~m}$. Climate type is arid and semi-arid, annual average temperature is $19-26^{\circ} \mathrm{C}$, and small changes with the season The rainfall of the area is characterized as bi-modal. Which is the $73 \%$ of rainfall occur in March to May, the $27 \%$ of rainfall occur in September to November [13]. The potential evapotranspiration is $700-3$ $000 \mathrm{~mm}[14]$. The study area is also dominated by savannah vegetation containing mixtures of perennial herbaceous vegetation.

\subsection{Sampling Procedure and Data Collection}

Three (3) kebeles (Dida Tuyura, Danbal-Waccu and Arero kebele) were purposively selected from Yabello district based on past experience showing willingness to adopt various technologies directly or indirectly used for scale up forage production including the current (Technology integration and demonstration of rangeland rehabilitation in lowland of Ethiopia) ongoing project. In each of the three kebeles, 70 households were sampled using systematic random sampling resulting in selection of 210 households for the interviews. And also from each kebele, two (2) agricultural and livestock extension workers were selected of total 6 professionals used us both for interviewed data collection and also as guidance of understanding the context to guide the design of the study approach and development of data collection tools. In total the data was collected from 216 individuals. A pre-tested questionnaire was administered to the selected households through face-to-face interviews to capture information on socio-economic and demographic characteristics of the respondents. This was done with the help of 6 extension workers who had been selected and adequately trained to give them full understanding of the questionnaire and the objectives of the study. In addition, Four (4) focus group discussions each comprising 15 participants, and 10 key informant interviews were conducted in each study site in order to get clarification and better understanding of the information gathered from household interviews [15]. The key informants were selected mainly based on their age, forage production experience, willingness of acceptance implementation of the service given by local extension worker, livestock production capacity and the main service providers drawn from government institutions and nongovernmental organizations.

\subsection{Data Analysis}

Descriptive and inferential statistical analyses were done using Statistical Package for Social Science (SPSS) version 22. Descriptive statistics including means, standard deviation (SD), frequencies and percentages were generated for the selected socio- demographic characteristics of the sampled households. Binary logistic regression was done to determine factors that influence participation in fodder production.

\subsection{Description of Variables (Both Dependent and Independent)}

The dependent variable used in the logit regression model was participation in forage production. The sample was classified into forage producers and non-producers based on the question whether the respondent was producing forage or not. The value of " 1 " was assigned to forage producing respondent, while " 0 " was assigned to a non-producing respondent. 
Table 1. Variables hypothesized to influence pastoralist participation on forage production technology.

\begin{tabular}{lll}
\hline Variable & Description & $\begin{array}{l}\text { Expected influence on participation of } \\
\text { forage production }\end{array}$ \\
\hline AGH & Age of household head (Number of years) & - \\
GEH & Gender of the household head (Male $=1$, Female=2) & \pm \\
EDH & Education level of the household head $(0=$ No education, $1=$ Primary, $2=$ Secondary, $3=$ Tertiary) & + \\
HLS & Household land size (Number of acres) & + \\
MFPPG & Membership to forage producing participation group (1= Yes, $0=$ No) & + \\
HHS & Household herd size (Total TLU) & + \\
AES & Access to extension services $(1=$ Yes, $0=\mathrm{No})$ & + \\
\hline
\end{tabular}

As we have seen from the above table the independent variables are age, gender and education of household head, size of land owned of household, herd size owned by the household, access to extension services, and membership to forage producing group involvement, which hypothesized to influence the dependent variable that is forage production methods.

\subsubsection{Age of Household Head}

Age of household head is a key factor that is expected to directly influence availability and access to production and livelihood resources [16]. According to different studies square of age is negatively associated with uptake of new technologies and his indicate that potential of household to exercise new technology is likely to decline after a certain age [17]. This told us when we compared younger household farmers with old household farmers; younger households are more risk takers and highly willing and initiative to change their lifestyle and farming practice through practice and adopt new technology and need to improve their income source. So based on this past experience, for this study we hypothesized that age has a negative relationship with adoption of forage production technology. So, the age of the household that were participated in our study were categorized and assigned the value of 1 if 30 years or less, 2 if $31-40$ years, 3 for $41-50$ years, 4 if aged between 51 and 60 year, 5 for $60-70$ years and 6 if above 70 years.

\subsubsection{Gender of Household Head}

In most African country including Ethiopia, females are limited opportunity to access and participate on the household farming practice including livestock production as compared to male. With regards to this aspect, women headed households are constrained by limited access to Natural resources and technology adaptation practice [18]. So, in this study we hypothesized that male headed household are more chance to involve and adapt forage production technology as compared to female household headed. And we assigned value of 1 was assigned to male headed households and 2 to female Headed households for this study.

\subsubsection{Education Level of Household Head}

Measured in terms of the number of years is spent by respondent in school. Education creates great acceptance and an opportunity for pastoral and agro-pastoral households to diversify their livelihood sources [19]. And better educated household have better understanding and perceive the benefit of new technology and apply it without any more doubt. As a result household level of education has a positive impact on forage technology adaptation and practice and we assigned the value of 0 if not educated, 1 if attained primary education, 2 for secondary education and 3 for household heads with tertiary education for this study.

\subsubsection{Household Land Size}

Land size of the household determines the amount of land that planned to forage production purpose. That means if the household have more/large land size the land size planned for forage production purpose too be large and if it is small total land size the part that used for forage production will be small. From this the hypothesis indicate that the land size has positive linkage with forage production and its technology adaptation and was assigned a value of 1 if 10 acres or less, 2 for $11-20$ acres, and 3 if greater than 20 acres for this study.

\subsubsection{Membership to Forage Producing and Participating Group}

If the households were collected together in the form of group, it helps to increases the capacity of group members to access services such as credits, extension and information. Participation in such groups is believed to strongly facilitate adoption of new technologies [20]. And based on this for this study we hypothesized that membership to social/development group has a positive influence on adoption of forage production technology practices by households and we assigned the value 1 to the households that are members to such groups, while 0 was assigned to households which are not members of a group.

\subsubsection{Household Herd Size}

Herd size of a certain household is become symbol of the wealth status of that family and we hypothesized that participation in forage production with adoption of new technology is dependent on number of livestock a household owns, and that there is a positive relationship between the two. And measured in terms of the total number of livestock owned by a household converted into Tropical Livestock Units (TLUs), where 1 TLU was equated to $250 \mathrm{kgs}$ mature live animal [18]. In this study, one bull was equivalent to 1.29 TLU, a cow $=1 \mathrm{TLU}$, a calf $=0.4 \mathrm{TLU}$ and a sheep or goat $=0.11$ TLU. Conversion of livestock numbers into TLU equivalent enables standardization of different animal kinds and classes into a universal unit thus aiding comparisons 
between household herds [18].

\subsubsection{Access to Extension Services}

Capacity building of pastoralists highly used to adopt new technologies by offering them basic and technical skills and knowledge on various production technologies. The current study hypothesized that access to extension services on forage production together with sensitization on the importance of the practice positively relates to adoption of forage production techniques. And we assigned for this study a value of 1 was allocated to household heads with access to extension services and 0 to household heads with no access to such services.

\subsection{Specification of the Binary Logit Regression Model}

The model choice for a study is based on the nature of the dependent variable and the objective of the study. The dependent variable in this study was binary that assumed two values; 1 if the respondent was producing forage by using technology and 0 if otherwise. This kind of variable is normally estimated using logit or probit models, both of which estimate parameters using maximum likelihood approach. While probit model assumes normal distribution error term, the logit model takes a logistic distribution of the error term. This study used the binary logit model due to consistency of parameter estimation associated with the assumption that error term in the equation has a logistic distribution [21]. The behavioral model described in the equations [22] below was used to evaluate factors that influence participation in forage production.

$$
\mathrm{Yi}=\mathrm{f}(\mathrm{ti})
$$

This means that there is a functional relationship (f) between the survey observation (Yi) and the stimuli ti, where,

$$
\mathrm{t}=\mathrm{bo}+\sum \mathrm{biX}
$$

$\mathrm{Y}$ is the response for the $\mathrm{i}^{\text {th }}$ observation with binary variable $1=$ producers and $0=$ non- producers. ti is the stimulus index for the $\mathrm{i}^{\text {th }}$ observation. It is presumed that there is a threshold index for each household, $\mathrm{ti}^{*}$ such that if $\mathrm{ti}^{*}>\mathrm{ti}$ the household is observed as a participant in forage production and if $\mathrm{ti}^{*}<\mathrm{ti}$ then, the household is a non-participant. The probability of such a household participating in forage farming technology was computed using equation 3 :

$$
\left\{P i=\left(e^{t i}\right) /\left(1+e^{t i}\right)\right\}
$$

The model for the factors hypothesized to influence households' decision whether to participate in forage production or not was then re-written as:

$$
\mathrm{Y}=\ln \{\mathrm{P}(\mathrm{Xi}) /(1-(\mathrm{P}(\mathrm{Xi})\}=\beta i \mathrm{Xi}+\varepsilon \mathrm{l}
$$

Where $\mathrm{Y}=$ the natural $\log$ of the probability of participating in forage production $(\mathrm{P})$, divided by the probability of not participating (1-P).

$\beta i=$ coefficient of factors influencing participation in forage production
$\mathrm{Xi}=$ factors that are hypothesized to influence participation in forage production

ei= error term

The linear regression model for this study was specified as shown in the equation 5 .

$$
\begin{array}{r}
\mathrm{Y}=\beta 0-\beta 1 \mathrm{AGH} \pm \beta 2 \mathrm{GEH}+\beta 3 \mathrm{EDH}+\beta 4 \mathrm{SZL}+\beta 5 \mathrm{HLS}+ \\
\beta 6 \mathrm{SMFP}+\beta 7 \mathrm{AES}+\varepsilon \mathrm{l}
\end{array}
$$

Several binary logistic regressions were conducted with participation in forage production as the regress and until the best fit of the model was obtained. The variables that best defined the estimated model was determined based on the coefficient of determination $\left(\mathrm{R}^{2}\right)$; adjusted $\mathrm{R}^{2}$, chi square value, the direction of influence of the independent variables, as well as the number of significant variables in the model.

\subsection{Multicollinearity Statistical Test: Variance Inflation Factor}

It was important ensure that the explanatory variables used in the binary logit model do not correlate with one another, a situation known as multicolliniarity, which occurs when two or more independent variables are linearly related. Multicolliniarity usually occurs in all sample data necessitating the need to test the level of its severity in the exogenous explanatory variables [23]. This was done through the test of the Variance Inflation Factor (VIF). Multicolliniarity was then eliminated through excluding or merging some variables during analysis so as to obtain a thrifty model. [17] Expression for empirical estimation of VIF was followed:

$$
V I \mathrm{~F}=1 / 1-R i^{2}
$$

Where $R i^{2}$ is the $\mathrm{R}^{2}$ of the artificial regression with the $i^{t h}$ independent variable as the dependent variable.

\section{Result and Discussion}

\subsection{Result of Multicolliniarity Test}

The VIF of the explanatory variables were found to range from 1.051 to 1.886 with a mean of 1.381 as shown in the Table 2. The fact that the VIF's for the independent variables were less than five $(<5)$ provided satisfactory justification for their inclusion in the logit model [24] as there was no serious problem of multicolliniarity.

Table 2. Multicolliniarity test for the explanatory variables included in the model.

\begin{tabular}{lll}
\hline Variable & Tolerance (1/VIF) & VIF \\
\hline Age & 0.776 & 1.288 \\
Gender & 0.951 & 1.051 \\
Education & 0.706 & 1.416 \\
Household land size & 0.530 & 1.886 \\
Group membership & 0.797 & 1.254 \\
Household herd size & 0.724 & 1.381 \\
Access to extension services & 0.718 & 1.392 \\
Mean VIF & & 1.381 \\
\hline
\end{tabular}




\subsection{Socio-demographic Characteristics of the Sampled Households}

The impact of socio-demographic features of the household on the forage production and practice of new technology were described below in table 3 and 4 . When we see the age, there was no difference $(p>0.05)$ in mean age between forage producers $(50.47 \pm 10.28$ years $)$ and nonproducers $(50.94 \pm 11.94$ years $)$. The results showed that forage producers were significantly $(p<0.01)$ more educated with mean of $9.14 \pm 3.99$ years of education than nonproducers whose mean age was $5.80 \pm 4.13$.. Households that adopted forage production had significantly $(\mathrm{p}<0.01)$ as compared to smaller average land sizes $(33.93 \pm 41.54)$ acres with large average land size (48.72 \pm 57.54$)$ acres, but larger herds sizes $(19.97 \pm 29.75 \mathrm{TLU})$ than non-producers who had averagely larger land sizes on average (48.72 \pm 57.54 acres) and smaller herds $(17.47 \pm 25.79$ TLU).

Table 3. Descriptive statistics for the hypothesized variables used in the model.

\begin{tabular}{|c|c|c|c|c|c|}
\hline \multicolumn{2}{|l|}{ Variable } & Producers $(\mathrm{N}=131)$ Mean & Non-producers $(\mathbf{N}=85)$ Mean & Chi-square & p-value \\
\hline \multicolumn{2}{|c|}{ Mean age of the household head in years } & $50.47 \pm 10.28$ & $50.94 \pm 11.94$ & 47.684 & 0.526 \\
\hline \multicolumn{2}{|c|}{ Years of education } & $9.14 \pm 3.99$ & $5.80 \pm 4.13$ & $53.699^{*}$ & 0.000 \\
\hline \multicolumn{2}{|l|}{ Household land size (acres) } & $33.93 \pm 41.54)$ & $48.72 \pm 57.54$ & $96.620^{*}$ & 0.007 \\
\hline \multirow{2}{*}{\multicolumn{2}{|c|}{ Household herd size (TLU) }} & $19.97 \pm 29.75$ & $17.47 \pm 25.79$ & 53.373 & 0.421 \\
\hline & & Frequency $(\%)$ & Frequency $(\%)$ & & \\
\hline \multirow{2}{*}{ Gender of households head } & male & $97(74.0)$ & $47(55.3)$ & \multirow{2}{*}{$8.157^{*}$} & \multirow{2}{*}{0.004} \\
\hline & Female & $34(26.0)$ & $38(44.7)$ & & \\
\hline Group membership & No & $34(26.0)$ & $65(76.5)$ & $52.989^{*}$ & 0.000 \\
\hline \multirow{2}{*}{ Access to extension services } & Yes & $103(78.6)$ & $16(18.8)$ & \multirow{2}{*}{$74.518^{*}$} & \multirow{2}{*}{0.000} \\
\hline & No & $28(21.4)$ & $69(81.2)$ & & \\
\hline
\end{tabular}

Most (74\%) of forage producer households were male headed compared to $55.3 \%$ for non- producers. In addition, most $(74 \%)$ of the forage producers were members of certain social groups compared to only $23.5 \%$ of the non-producing households (Table 3 ). More (78.6\%) forage producers had access to extension services than non-producing households $(18.8 \%)$. From these result we can understand that gender, education level, size of land owned, group membership and access to agricultural extension services important factors that may influence participation in forage production among the pastoralist communities in the study area. These result in agreement with Kaliba [25] who reported similar factors amongst others to be primarily important in influencing adoption of agricultural technology.

\subsection{Results of the Binary Logit Regression}

Table 4 shows the results of the binary logit regression model. Seven variables were tested of which five were found to significantly influence forage production uptake by households. The independent variables were found to explain $57 \%\left(\mathrm{R}^{2}=0.57\right)$ of the variation in households' participation in forage production in the study areas. Gender of the household heads had a positive and significant $(p<0.05)$ influence on households' participation in forage production, implying that the male headed households were more likely to participate in forage production than those headed by females. This could be explained by the fact that men have better access and control over important resources such as livestock, land and financial capital than women [26]. In addition, this finding could be associated with the high labour requirements of the practice and the domestic responsibilities of women in the societies which limit time, their access to agricultural information, trainings and extension services [4]. The marginal effects show that facilitating both gender participation would increase chances of adopting forage production technologies by $20 \%$.

Education level of the household heads showed a positively significant $(\mathrm{p}<0.05)$ influence on the possibility of a household participating in fodder production, suggesting that household heads with higher education levels have higher chances of undertaking fodder production, unlike their counterparts with no or less education. Participation in a group and access to extension services showed positively significant $(\mathrm{p}<0.01)$ influence on households' participation in forage production. This implies that household heads who participate in groups and with better access to agricultural and extension services were more likely to adopt forage production technology. Specifically, the marginal effects explain that group membership of an individual increases their probability of adopting forage production technologies by $29 \%$, while a unit increase in access to extension services increases adoption of forage production chances by $49 \%$. This could be linked to the fact that working in organized pastoralist groups has many benefits such as easier and enhanced access to financial and extension services [26], as well as free or subsidized inputs such as startup grass seeds. Government institutions, as well as NGOs have successfully implemented many agricultural development programs through working with pastoralist groups. Household herd size was found to have a positive and significant $(\mathrm{p}<0.05)$ relationship with adoption of forage production, indicating that households with large herds have higher probability of adopting forage production than those with smaller herds. This is because, under the current situation where there is decline in natural pastures due to climate variability and change, sustaining large herds call for strategies to avail extra feed resources, and therefore making adoption of various production technologies necessary. Traditionally, pastoralist households with large herds tend to remain mobile especially in the dry seasons when pasture is scarce. However, the 
challenge of diminishing communal grazing fields due to changing land use and tenure have restricted mobility as a coping strategy. This situation could be regarded as a catalyst to establishment of forage farms by livestock keepers with larger herds.

Table 4. Logit model estimates for the determinants of household's participation in forageProduction.

\begin{tabular}{|c|c|c|c|c|c|}
\hline Variable & $\boldsymbol{\beta}$ & Wald & $\operatorname{Exp}(\beta)$ & Marginal effect & p-value \\
\hline Age & $-0.034(0.021)$ & 2.688 & 0.966 & $0.008(0.005)$ & 0.104 \\
\hline Gender & $0.878 * *(0.420)$ & 4.367 & 2.407 & $0.200(0.976)$ & 0.040 \\
\hline Education & $0.141 *(0.052)$ & 7.326 & 1.151 & $0.003(0.115)$ & 0.007 \\
\hline Household land size & $-0.007(0.005)$ & 1.537 & 0.993 & $-0.001(0.001)$ & 0.217 \\
\hline Household herd size & $0.015 * *(0.008)$ & 2.988 & 1.015 & $0.003(0.002)$ & 0.085 \\
\hline Group membership & $1.318 *(0.403)$ & 10.699 & 3.736 & $0.289(0.085)$ & 0.001 \\
\hline Access to extension service & $2.333 *(0.414)$ & 31.706 & 10.306 & $0.492(0.074)$ & 0.000 \\
\hline
\end{tabular}

Statistical significance level: $* 1 \%, * * 5 \%$ and $* * * 10 \%$; Chi-square $(\mathrm{DF}=7)=117.99(\mathrm{p}<0.001)$; $-2 \log$ likelihood=171.577; Cox and Snell $\mathrm{R}^{2}=0.421$; Nagelkerke $\mathrm{R}^{2}=0.570 ; \mathrm{N}=216$; Standard error in parentheses

\section{Conclusion}

The results of this study indicate that gender, group membership and access to extension services are the most important factors determine households 'participation in forage production in the study areas. Household heads that have access to extension services and are also members of social groups have the highest chances of adopting forage production. This is due to the fact that extension workers and other supporting organization prefer to reach out to the producers through organized groups. On the basis of the results of this study, interventions aimed at facilitating households' participation in forage production should support formation and strengthening of forage producing groups as way of enhancing information sharing, as well as increasing producers' access to agricultural information and extension services. So based on this finding we recommended that efforts towards out-scaling forage production should target access to extension services and support households to start and (or) join existing groups, which are known to be avenues for accessing extension services with the ultimate goal of ensuring sustainable and efficient forage production in the drylands.

\section{Acknowledgements}

We would like to acknowledge University of China academy of science that give us any facilities and finical support to do this research paper as well as our great thanks also goes to the Yabello Pastoral and Dry land Agricultural Research Center to provide all laboratory facilities and also all the laboratory technicians to their continues fellow up and support throughout the study was completed. And also our great thanks goes to the local community of the Yabello district for gave us those basic information and also indicate the factors that are still the challenge for them for our next research step.

\section{Conflicts of Interest}

The authors declare that there is no competing of interest.

\section{References}

[1] Alemayehu, M. 2004. Rangelands Biodiversity: Concepts, Approaches, and the Way Forward. Addis Ababa, Ethiopia.

[2] Kassahun, A., Snyman, H. A., and Smitt, G. N. (2008). Livestock grazing behaviour along a degradation gradient in the Somali region of eastern Ethiopia. African Journal of Range and forage science. Volume25 (1) 1-9. Retrived from: http://www.tandfonline.com/doi/abs/10.2989/AJRFS.2008.25. 1.1.379. Accessedon 11/12/2015.

[3] Alemayehu Mengistu. 2003. Country Pasture/Forage Resource Profiles.

[4] Kidake, B. K., Manyeki, J. K., Kubasu, D., and Mnene, W. N. (2016). Promotion of range fodder and fodder production among the pastoral and agro-pastoral communities in Kenyan rangelands: Experiences and lessons learnt. Livestock Research for RuralDevelopment, Volume 28. http://www.lrrd.org/lrrd28/8/kida28151.html Long, J. (1997). Regression models for categorical and limited dependent variables. Thousand Oaks, CA: Sage Publications.

[5] Joosten, K., Ekodere, P., and Miano, G. (2014). Best Practice Brief- Fodder production in Baringo County. Article available at: http://asalsmarkets. wikispaces.com/file/view/Best+practice+br ief ++ Mayiani + fodder+group $+(2)$.pdf. Accessed on 13/03/2017.

[6] Tilahun A, Teklu B, Hoag D (2017). Challenges and contributions of crop production in agro-pastoral systems of Borana Plateau, Ethiopia. Pastoralism 7 (1):m2.

[7] Hasen YM (2013). The influence of land use and cover changes on the pastoral rangeland systems of southern Ethiopia - How much woody cover is enough? Ph.D. Thesis, University of Hohenheim.

[8] Gemedo- Dalle, T., Isselstein, J. \& Maass, B. L. (2006). Indigenous ecological knowledge of borana pastoralists in southern Ethiopia and current challenges. International Journal of Sustainable Development \& World Ecology, 13: 113-130.

[9] Daniel J (2010). The extent of Bush Encroachment and Its Impacts on Selected Soil Properties in Borana Rangeland, Ethiopia. MSc. Thesis, Hawassa University Wonndo Genet College of Forestry and Natural Resources, Integrated Watershed Mangement. 
[10] Ayana A, Gufu O, Adunya T (2012). Bush Encroachment Control Demonstrations an Management Implications on Herbaceous Species in Savannas of Southern Ethiopia. Trop. Subtrop. Agroecosyst. 15: 173-185.

[11] MacOpiyo L., Irungu, P., and Elhadi, Y. M. (2013). Study Of Livestock, Fodder, Milk Production And Marketing In Arid And Semi-Arid Lands Of Kenya Under - "Promotion And Strengthening Enterprises And Market Systems In DroughtProne ASAL Areas" Baseline Report For Kajiado, West Pokot and Narok Counties.

[12] Manyeki, J. K., Kirwa, E. C., Ogillo, P. B., Mnene, W. N., Kimitei, R, Mosu, A, and Ngetich, R. (2015). Economic analysis of natural fodder rehabilitation through reseeding in the southern rangelands of Kenya. Livestock Research for Rural Development. Volume 27, Article no. 49.

[13] Dalle G, Maass BL, Isselstein J. Rangeland condition and trend in the semi-arid Borana lowlands, southern Oromia, Ethiopia [J]. African Journal of Range \& Forage Science, 2015, 23 (1): 49-58.

[14] Billi P, Alemu Y T, Ciampalini R. Increased frequency of flash floods in Dire Dawa, Ethiopia: Change in rainfall intensity or human impact? [J]. Natural Hazards, 2015, 76 (2): 13731394.

[15] Nyaoga, R. B., and Magutu, P. O. (2016). Constraints management and value chain performance for sustainable development. Management Science Letters 6 (2016) 427-442.

[16] Lugusa, K. O. (2015). Fodder Production as an Adaptation Strategy in the Drylands: A Case Study of Producer Groups in Baringo County, Kenya. MSc Thesis, University of Nairobi.

[17] Omollo Erick Ouma. (2017). Analysis of fodder production and marketing in the Rangelands of southern Kenya (unpublished data).
[18] Wasonga, V. O. (2009). Linkages between Land-use, Land Degradation and Poverty in Semi- Arid Rangelands of Kenya: The Case of Baringo District. PhD Thesis, University of Nairobi.

[19] Muyanga, M. (2008). Household Vulnerability to Transient and Chronic Poverty: Evidence from Rural Kenya. Tegemeo Working Paper No. 21, Tegemeo Institute of Agricultural Policy and Development, Egerton University.

[20] Salasya, B., Odendo, M., and Odenya J. (1996). Adoption of improved sorghum and other production technologies in Busia District Kenya. Proceedings of the $5^{\text {th }}$ KARI scientific conference.

[21] Ravallion, M., (2001). "The Mystery of the Vanishing Benefits: An Introduction to Impact Evaluation." The World Bank Economic Review 15 (1): 115-140.

[22] Gujarati, D. N., (1995). Basic Econometrics. 4th. Edition. MacGraw-Hill, inc. New York. Pp100-343.

[23] Koustoyiannis, A., (1973). "Theory of Econometrics." Macmillan Press Ltd.

[24] Maddala, G. S. (2001). Introduction to Econometric, 3rd edition. Wiley and Sons Inc, 32.

[25] Kaliba, R. M. A., V. Hugo, W. Mwangi, J. T, A. Mwilawa, A. Poniah and A. Moshi. (1998). Adoption of Maize Production Technologies in Central Tanzania. Retrieved from: $\mathrm{http} / / / \mathrm{www}$.tanzaniagateway.org/docs/adoption of maize pro duction_technologies_in_central_tanzania.pdf. Accessed on $17 / 10 / 2016$.

[26] Olila, D. O. (2013). Economic Evaluation of Factors Affecting Farmers Participation in Development Groups: A Case of Trans-Nzoia County, Kenya. Journal of Agricultural Economics, Extension and Rural Development: ISSN-2360798X: Vol. 2 (6): pp 074-081, June, 2014. 